\title{
Erratum to: Four polymorphisms in cytochrome P450 1A1 (CYP1A1) gene and breast cancer risk: a meta-analysis
}

Theodoros N. Sergentanis •

Konstantinos P. Economopoulos

Published online: 30 July 2010

(C) Springer Science+Business Media, LLC. 2010

Erratum to: Breast Cancer Res Treat (2010) 122(2):459-469

DOI 10.1007/s10549-009-0694-5

The authors would like to replace the typographical error

"Thr461Asp" by "Thr461Asn" throughout the article.

The online version of the original article can be found under doi:10.1007/s10549-009-0694-5.

T. N. Sergentanis · K. P. Economopoulos School of Medicine, National University of Athens,

Athens, Greece

T. N. Sergentanis $(\bowtie) \cdot$ K. P. Economopoulos

Society of Junior Doctors, Athens, Greece

e-mail: tsergentanis@sni.gr

URL: www.sni.gr 